\title{
THE GANGA PARADOX
}

\section{INES PRICA}

The intention of this paper is to focus on the symbolic fate of an 'unusual' folklore expression which, thanks to is indisputable authenticity, has broken through to the status of internationally protected World Intangible Heritage while, at the same time, it has been stalked by the long-term and unsolved controversies of local political taboo and subversion. Keywords: ganga, Dalmatian hinterland, Western Herzegovina, political folklore, intangible heritage.
Namen prispevka je pozornost simbolični usodi 'nenavadnega' izraza folklore, ki se je, zahvaljujoč nedvoumni avtentičnosti, prebil na mednarodno zašciten položaj na seznamu svetovne dedišcine, hkrati pa ga spremljajo dolgotrajne in nerazrešene kontroverznosti lokalnega političnega tabuja in subverzivnosti. Ključne besede: ganga, dalmatinsko zaledje, zahodna Hercegovina, politična folklora, nesnovna dedišcina.

During the two decades of Croatian transition which, in the shadow of culturological discussions on Croatia's 'belonging to Europe', darkened and legalised economic and social crime of horrendous proportions and consequences, the ganga phenomenon extended over a broad symbolic span where, in the function of an entrenched social mentality of sorts, it appeared in a controversial range: from the mythic and unsullied area of 'proto-European' values, rejected by the impact of decadent Western civilisation, to completely opposite denotations of social regression at the very base of identity formation founded on autism and intolerance.

What is the ganga, anyway, according to the specific folklore expression denoted as a cultural 'gaffe' that makes it a hard nut to crack in aesthetic evaluations but also in identity formations, in all historical and cultural derivations of European affiliation? Group cantare sul fiato in major seconds intervals, part-singing made up of the initial voice singing the lyrical verse then joined by the associated ojkanje vocals, is part of the centuries-old system of music-making denoted as one of the last refuges of archaic music thought. Drastically different from the dominant western music canon, with the lyrical verse inserted into the field of heroic 'Hajduk epic poetry', the ganga clearly follows the rules of social stratification in its controversial reception, ranging from local devotion to it on to the odium encountered in urban environments that experience it as being coarse, primitive and nontempered singing. In the framework of the expert community, the pentatonics of the ganga has been a cultural-historical theme of identification from as early as the 1930s, where its models were sought in the pre-Slavic Balkan substrate, but also in various 'early cultures' throughout the world, even including the music of the Native American Indians. Efforts at its affirmation in Southern Slavic tradition saw it as a remnant of pre-Slavic Balkan music practice, in which the function of 'a resistant force in the aeons of suffering and 
struggles against oppressors' was manifested in a melodic reduction to diaphonics. That contrast with the western music canon, inherent as an almost unbearable physiological audio 'discordance', keeps it in the constant focus of culturological negotiations about its status in national traditions.

As a 'wild' element inserted into the tameness and harmony of popular spiritual creativity, the ganga thus covers the Protean range of interpretational potential, from signs of the mystic pre-cultural state of universal messages to the symbols of inveteracy and local fascination.

The hesitant nature of national-aesthetic evaluations, additionally supported by the multi- or trans-ethnic character of its unfathomed origin, was finally brought to an end by the ganga's recent insertion in UNESCO's list of World Intangible Cultural Heritage. Expert judgement has decided to the benefit of harmonious polyphony in narrow intervals, by which that nondescript jarring of the ears has also been officially transposed into 'the perfect effect of audio unity' (cf. on this point, Ćaleta 2009), while taking a relatively indifferent stance towards the performance aspect of the language of the ganga in its local framework.

Between singing and talking, the function of the message and the sound being divided in the communications sense, the ganga also resists the genre-based clarity of oral literature. By verse that does not necessary imply rhyme and 'frozen' images of Nature and everyday life, it frequently entices comparisons with haiku poetry, but the lyrical topoi, and particularly the inclination to the language of the absurd, are also linked with strict contextual meaning. Casting in decasyllabic verse that also allows the unusual directness of the message assigns the ganga the 'male' epithet of a crude and profane song, when sexual and political content is in question.

Performance of the ganga in contemporary field status therefore follows the externally imposed logic of its ambivalent nature, so that in the adopted selectivity and mimicry of the local community, only 'lovely' gangas are put on show for the first impression, usually confirmed by performances on stage, with appearances in Zagreb as the ultimate confirmation of its acceptance. For its part, entry into the ambience of the 'uncouth' and politically subversive ganga requires an outsider strategy that promises understanding, empathy and, possibly, a sharing of delight in the taboo.

This contextual demand for cultural intimacy and conspiracy whose final objective is catharsis and self-revelation is also connected - apart from the erotic connotation - with the ganga's 'Ustashi' connotation since the mid- $20^{\text {th }}$ century. The folklore character of this form of music-making, which offered an acceptable variant of multi-culturalism as a Balkan 'proto-ethnic' amalgam, did not make it possible - particularly from the $1970 \mathrm{~s}$ - for the ganga to be enthroned as a symbol of Croatian nationalism in its political-loser renegade attribute and Diaspora 'guest-worker' culture. Taking on many of those elements in the 1990s, but now under the 'winner' status of the newly-acquired independence and setting the record straight with Socialism - particularly the symbolics of suffering from the 
'Communist crimes' - ganga culture, in the broader regional perception, but also within Croatian rural and urban binarism, became a general symbol of primitivism and sociocultural regression, the standard-bearer of a new stratum of power-wielders from Dalmatian Zagora and Herzegovina (see Petrović, 1995)

By the sub-cultural positioning of its utterance practices, the ganga thus continued to incline towards full national and traditional affirmation, while at the same time taking the place of a recognised folklore term of reference in the national domain, but also symbolically in shaping 'the ganga-territory' of Croatian European affiliation.

The controversial history and the chaotic political infrastructure and neglected social interests of the Dalmatian hinterland region (Zagora) and (Western) Herzegovina, still most neutrally presented anthropologically by its Dinaric characteristics, owes its contemporary symbolic representation largely to the wartime revitalisation of the conserved historical nexus and the reproduction of 'Morlachisms' as a domesticised variant of European imagological repertoire. Due to the fact that the region was denoted 'by the ambivalence of Christianity as the concept of the border of Europe' in Croatian political history from the Middle Ages to the end of World War II, popular culture was traditionally shaped there in some form of resistance, with the major social role of the 'heretical' Franciscan Church and the Hajduk epic tradition. The high participation of the Western Herzegovina population in the establishment of the Independent State of Croatia [the $N D H]$ during World War II was prompted by their desire to become part of Croatia after the establishment of the 'unnatural' border between Croatia and Bosnia-Herzegovina, and the Peace Treaty of Karlowitz with the Ottoman Empire, which had divided "the same people with the same language, the same customs and the same political aspirations" (cf. Bašić 2006: 23). The Ustashi stigma that also branded the next generation, along with economic neglect, was a major cause of the mass emigration after World War II to the countries of western Europe (but also to Canada, the United States, Australia and New Zealand), so the guest-worker influence became crucial in the cultural hybridisation and social imbalance of the region, but also in the economic dimension of the wartime creation of the Croatian state. An almost invisible element in the Croatian national corpus, largely perceived until then through the controversial determinant of the 'Croatian Diaspora' and films on the pitiless exotics of some semi-identified geographically rocky territory, returned to the scene at the beginning of the 1990s, under circumstances that imposed a reproduction of sorts of the 'Hayduk' model of political and social intervention in Croatian transitional reality.

\section{ANTEMURALIS: BUT FROM BOTH SIDES OF THE BULWARK}

In the 'transitional' renewal of its symbolic status, however, the innovative nature of the post-socialist juncture was recognised precisely as an opportunity to break with the tele- 
ological and linear character of the Utopian narration by the suggestion of the possibility of instantly 'becoming the West' through attainable, almost routine mechanisms of procedural transplantation of a democratic social system. Consequently, the urgency of the post-socialist periphery was solved through the act of implementation as a retroactive node of transitional narration. The projective nature of the ideological plot for progress was replaced by the 'ideology of presence' in which every variant of the forerunning and 'collateral' outcome of the act of implementation was valid and legitimate, in principle.

In relation to the 'Euro-Asian type' of post-socialist transformation that functioned largely as a mode of primary accumulation of capital, Europeanisation was also set as a procedure of legalistic anchoring of the status quo of democratic processes gone astray. The post-Utopian character of accession to Europe thus consists of the 'fabled return' through the institutional act of signing, counting on some matter-of-principle European-ness, both prior to and subsequent to the act of democratisation itself.

The question of the absence of Croatian national pride could then be eliminated by the far from spectacular and disappointing nature of the act that confirms that '(we know) that we are already Europe'. Presented as the finale of the long-term, exacting and, in the end, successful undertaking of 'negotiation by headings', the signature placed the entire field of collateral discourse, referred to according to the problematic nature of culture and identity, in the area of 'democratic surplus', a free, admittedly, but potentially dysfunctional game of exhausting engagement and settling of accounts around the historical topoi, cultural markers and symbolic registers that 'stand for where we belong'.

From here it seems that the culturisation of the European question through the vast intellectual investment in examination of the relation between the centre and the periphery, which finally flowed over into a paralysing vacillation about the adequate form of theoretisation in the overall amortising function of the actual effects of the political agendas. In the fabulous reversion of the discourse related to Europeanisation, negotiation with the periphery was once again necessarily recognised in its genealogical-geographic status, emerging from a barely legitimate position as objecting to the imaginary nucleus of domination.

However, European post-socialism reproduces the deviation of the enlightening nexus with only occasional conditions of peripheral colonisation. The 'nucleus' is now manifested in its structural status quo position, in the institutional act of signing as the final recognition of the presence of each and 'everyone's' European-ness. That object, the non-discursive status of anti-identity represented by the faceless authority of European bureaucracy, now integrally and no longer partially 'oversees' the domain of European subjects. The position of the periphery is open in the area itself of the European nucleus as a social, humane substance, so the entire complex of communication with the 'actual' periphery can be taken at the same time as both postponing and anticipating that structural collapse, the post-colonial unity of European society as a whole. 


\section{RETURN TO THE BULWARK}

The theme of Croatia's return to Europe and of Croatia as Europe's bulwark inverted the narration, and also the process itself of transitional transformation in 'the opposite direction', in a search for certain clear-cut definitions of the European identity of the new state, determinable in Croatia's historical and cultural heritage. Intellectual discourses were successfully harnessed as a decontextualised element in the populistic rhetoric of 'fortifying' the nation, despite the fact that their historical veracity was disputed to tragicomical turns of events. Apart from that, their rhetorical efficacy, shaped in an atmosphere of overall historical revisionism after the disintegration of the Yugoslavian state, rests precisely in the experiential cognizance of the exchangeability of topoi and 'routes' by which the desirable history of states and nations is formed. The manipulative potential of those representations lies not so much in the proverbially termed 'stupidity of nationalism', as in that profound suggestion of the arbitrariness of the connection between actual experience and the (national) narration, which latently favours the alibi for vast political and social deviations in the second period of the transitional partyocracy.

Systematically unmasked and even ridiculed as a provincial reflex of the new political elite in their search for cultural avowal, the metaphor of 'the return' (on this point see Lindstrom 2003) initially persevered with identification of national tradition and creativity in the so-called high canonical history of European culture, while from its unending repetition from the political platforms it was finally reduced to a mere coffee-house cliché on how, for some reason, we had 'always been Europe'. Reduction in the criteria of Europeanness in the two decades of work on the transitional narration in keeping with increasingly 'lighter' indicators of popular cultural similarity in lifestyle and everyday life has, with time, merely served to confirm fellowship in the economic crises and the necessity for pruning the public sector and, in the finale, the common heroic struggle against corruption and crime, as necessary by-products of the obstinate remnants of the past and social processes that 'have fallen behind' in relation to the model of the new political and cultural identity.

The bulwark concept could, unlike the doubtfully sincere call to engagement in the blueprint of creative culture, also encompass that 'fall in the norm' of belonging to Europe, orientating it towards the reservoir of historical merits and the qualitative difference among 'anthropological types, the warrior institution, Christians and the traditional European'. In the necessity for establishing the continuity of that 'proto-state European being', precisely that category of conditional and ambivalent belonging, the marginal identity that dwells on the 'infected' borders of European-ness, is privileged. In its thankless position between 'the West that is rotting away' and 'the East that is making inroads', the bulwark is being interiorised as the gulf in awareness of self, a form of autoreflexion that represents its 'backward' subject, struggling simultaneously, as with a foreign body, against its own interiorisation of the 'evil erudition' of the West. The pathos of this Weltschmertz from the periphery drifts between the worst of choices, between the unfortunate position of 
national betrayal and of local alliance in the defence of the uncorrupted region of Europe, as a bulwark for Europe within Europe itself.

However, as an argument in favour of its belonging to the West - just as strong as the attempts at its denial had been - the 'bulwark' largely blocked the way to the onslaughts of direct Croatian $20^{\text {th }}$ century history, with veiled or explicit suggestions that socialism itself had somehow been imposed upon Croatia from the East. It was also from that position that the suggestion of an internal enemy of transition was touted as decadent, along with the objectivisation and 'territorialisation' of the idea of some entrenched social character responsible for its devastating deviation, an idea that was also well aided by local rationalistic discourses during the 1990s, including those of the social sciences (cf. Prica 2007a).

Locating the unidentified 'post-socialist subject' as the main problem in the destruction of Croatian post-war society, analyses altered their heading to the underground introduction and legitimisation of pseudo-psychological and loser-mentality characterisations, as the democratisation of the incapable majority that lacked enterprise, thus helping whether consciously or otherwise, the illusion of an arduous and sincere internal political struggle for acceptance of the European path on the part of the ruling clique. Connecting on to the popular-science interpretation of the Yugoslavian conflict of the 1990s, in which certain Western anthropological methodologies experienced their great fiasco, falling into mythological-mentalist interpretation of ethnic conflicts, domestic intellectual forces had the difficult task of bridging the diverse conceptions of post-Socialist 'regression consciousness' symptoms. While the Balkanistic discourses hovered on the borders of epistemological validity, with implicitly placed ideas on nationalism as a collective spirit transposed into some pre-political state of tribal reflex, certain domestic 'liberal' analyses endeavoured to point out that the so-called re-traditionalisation of Croatian society was an essentially unambiguous category of inherited socialist mentality (cf. Prica 2007b). More immanent to both currents was criticism of 'awareness' rather than social processes, of 'mentality' rather than the political system, and of 'symbols' rather than indicators that would have underscored the headlong fall of Croatia into the economic and social 'bulwark' of postsocialist processes and societies.

The conditions of 'later post-Socialism', characterised by the revelation and location of the backdrop to failure in the destructive activities of the political elite, was denoted by the enormous growth in public criticism that crashed like waves against the cliffs of the majority parliamentary democracy. As a result of the erosion of its fundamental predispositions, meetings of the Croatian Sabor, or parliament, were reduced to caricature, the pseudo-social terminology of the political majority was 'thrown back' in an ironically over-saturated public discourse, in the food chain of circulating criticism that harvested its lucrative surplus in the ostensibly independent operations of media capitalism. Speech of authentically social character in this type of discourse constellation was brought into question in its fundamental, 'ontological' predisposition. The deconstruction of ethnonationalistic, alias 'constructivistic' identity policies on the one hand, and the de(con) 
struction of intellectual and analytical heritage of the leftist 'failed project' on the other, with a lack of convincing protagonists from the democratic public, puts the question to each and every slightly authentic critical and analytical discourse: all those speeches are presumed to be 'in the name' of which people, which social stratum, and which community?

Deconstruction of the post-socialist subject thus conditions the necessity for identification of the 'replacement object' that would, at a minimum of its social, class or ethnic definition, support the maximum role of the hard-headed Otherness of Western democracy. That object now pleads for anchorage in some place of culture, so that the reproduction of stereotypes takes place in some sort of mini-Balkanistic procedure, through the actions of nested Orientalism celebrated in song which, however, are increasingly declared to be the product of an analytically critical subject.

The installation of the 'neutral' quality of cultural differences at the pinnacle of the discursive chain produces a hierarchisation of cultural values in their increasingly mundane interpretations, right up to the final act of someone's self-recognition in the matrixes of the 'deconstructed' Eurocentric principles, as the only mode of self-evaluation of one's own identity position.

\section{GANGA-TERRITORY}

The mapping of this stubborn Otherness in the semantic inertia of popular theories took place in keeping with the recognisable co-ordinates of descent along the 'civilisational incline'. As a cross-section of multiple and divergent stereotypisations of cultural and anthropological differences and types, which survive undisturbed by the analytical disclosures of all the Eurocentric, Mediterranean, Oriental and Balkan discourses, that Otherness appears as an unprocessable retroactive surplus of enlightened meta-narrations. The cunning intelligentsia of the Croatian transitional narration would store there an entire reservoir of the 'reserve' values of its identity, characteristics that could simultaneously function both as its 'most European' and as its 'most non-European' attributes. Although unnameable because of its ambivalent, symbolic and actual nature, I shall nonetheless name that place gangaterritory. Under the arms embargo by which the international community thought to stop the bloody conflict, the packages of cash that arrived along the corridors of nostalgia and conserved patriotism largely went astray on the still uncharted trails of capital accumulation, representing the inauguration of the wartime model of Croatian transition. The stereotypisation of contemporary Herzegovinian warrior identity also uncoiled in the controversial framework in which the heroic defence of Vukovar on the part of Herzegovinian descendents in Slavonia shattered into the devastating Bosnian-Croatian conflict. However, the greatest symbolic contribution to the Hercegovinians as the hetero-topos of Croatian transition was conducted through variations on the theme of their entrepreneurial character. That initial 'breath of capital', because of which they had been previously celebrated both as authentic 
patriots and standard-bearers of global modernity, made them the attractive object of the concatenation in which there was an absence of a border between entrepreneurship and social banditry - as the generally unsolved nexus of (Croatian) economic transition. The juxtapositioning of moral and loser mentality, social skills and law-breaking, Christianity and capitalism, and 'heroism and felony' as the framework of moral and political as well as legislative wavering around the social consequences and ideals of that period, made it possible in one and the same packet to signify them by the crime of materialistic insatiability and political Machiavellism. The conditions for such hybridisation of disjunctive particularities which, as the practice of simultaneous inclusion and exclusion implemented on the borders of identity, were made possible by the very character of the transition as 'almost but not quite' (cf. Bhabha 1994) Western democracy. In the generally ambivalent verdicts on the 'innovations' of post-Socialist 'entrepreneurship', the short-cuts and by-ways by which the processes of economic and social 'restructuring' of Croatian Socialist society unfolded were abandoned for decades to the indifferent evaluation of 'the judgement of time'. Subjected to criticism from abroad almost exclusively because of its morally (and 'aesthetically') questionable nationalistic character, Croatian society behind the finally implemented masks of European political internationalism, disintegrated with time along its Frankenstein's monster-like seams of the compromising nature of its transition, palmed off in the matrix of cultural debates and the internal schisms of its national identity. In one of the initially installed transitional discussions on the distribution of cultural substance in the Croatian space, the fundamental conflict between rural and urban culture (which was renovated in the platitude on 'the inroads by wild mountain-men' by variants in the regional interpretation of the war on the territory of the SFR of Yugoslavia), the Hercegovinians ended their symbolic transition in the full 'post-analogical' status of newcomers who interfered in the refinement and inertia of urbane style with their forcefulness and primitivism.

Granted amnesty from the role of the 'whipping-boy for numerous Croatian frustrations' in the more recent wave of rationalisation and interiorisation of political accountability, the Herzegovinians would be reduced to the banal emanation of their 'bad' image. The urban fetishism of European 'post-colonialism' has assigned the contemporary image of the Herzegovinians almost exclusively to the area of cultural derision, the ironical meta-status of apish imitation of their own 'simulation of culture'.

However, the notorious style of wearing white socks, even with more formal male attire, was not merely a pathetic attempt at inclusion by a confused anachronistic identity in the elusive current of urban modernisation. To the contrary, juxtapositioning of an item with the fetishist meaning of the native place and the West is continuous in the domestification of foreign experience and includes the affirmative gesture of self-recognition in cultural diversity. In that way, the guest-worker aesthetic, in the emptiness of one's own image of oneself, triumphantly 'restores' the particular experience as the general early experience of Europe. 


\section{FISSURES ON THE RIVIERA}

Setting aside the Dalmatian Other from the Herzegovina reservoir of tragic guilt was part of the political ambience of the so-called second transition, marked by final confrontation with the accountability of the national elite for the 'unforced' errors of the Croatian post-war period. The new distribution of the political infrastructure after the tide-turning elections of 2003 introduced reconciliatory social-democratic rhetoric which, for its part, was also underscored by the incapability of facing up to the consequences of the clannishnepotistic activities of the oligarchy during wartime transition. Keeping mum on the actual nature of the Croatian 'switch-over' to capitalism, as a suspicious legal and selfish backdrop to the defence dimension of the war, made possible a short-term stabilisation of the political discourse, when Croatian also became an official candidate for EU membership. However, the recidivist nature of the far-reaching political and social consequences of the wartime social and economic crimes remained an insidious threat, withdrawing from the correctness of the 'metropolitan' discourse towards the refuge of the Croatian South, as its symbolic territorial niche.

The events on the City of Split's Riva in 2005 - where the 'people' rose up forcefully in 'defence of the Croatian generals' before the Hague Tribunal, threatening dangerous political disintegration and even civil war - were indicative of the serious internal fissures in the national narration. Led by the future Croatian premier, the Split-born theatrologist, Ivo Sanader, the 'righteous' masses on the Riva, in primarily culturologically different columnist-critical discourses, were once again presented in their mountain-man Wallachian element. As newcomers on the Riva, the interlopers descent into 'Diocletian's, 'red', 'urban' but, in any case, dolce far niente and politically somewhat indifferent Mediterranean city, was also to augur Split's next Balkan Croatian event, the stoning of the Gay Pride parade in the Spring of 2011, which occupied a chronologically awkward position under the aura of the European signature.

However, prior to proclamation of the most explicit 'European' discourse since Croatian independence, the political message of the briefly disenfranchised but still powerful transitional elite flowed over into popular culture, where, in what was then the peaceful atmosphere of the fully 'culturalised' public political sphere, it was implemented as an unsanctioned release of the refuse of its political correctness. Controversially grafted into the 'urban pop scene', the radiating core was taken over by the Croatian war veteran, Marko Perković Thompson, taking his name from his wartime weapon, a promoter of Croatian-ness as a historically threatened category. In a postmodern pastiche of 'CrusaderBarbarian' stage symbols, the appeal was made there for the mythic native place of a parapeople in defence of universal human and natural worthiness (cf. Prica 2009). Through the names of the enemies - Turks, Serbs Communists - one can detect his mythic place: a chronotope of the bulwark forced back under the influence of corrupt civilisations to the remaining Dinaric fragment. By conquering the centre, legitimate state territory, the saga 
of national identity as an authentic Christian calling was celebrated in song from the taboo of narrow intervals in attractive shepherd-rock, where the harmony of the Mediterranean thirds pleasantly parried Balkan melismata, as a reminiscence of 'heretical' ganga seconds.

In that way, Thompsonism became a model of sorts for the 'sandwich-culture' of the prospective new parliamentary majority - sworn 'fingers crossed behind their backs' Europhiles - and, after a brief interval, they were returned to power triumphantly in the next elections. The concerts of the enormously popular singer, whose message became a satellite mission of paradoxical European anti-globalism through the branches of the Croatian Diaspora, advanced in a campaign from obscure village stages to as far as to Zagreb's central city square.

In the culturally irresistible combination of political charm that united the socialdemocratic major of Zagreb, who was originally from Herzegovina, and the Croatian Democratic Union premier, a full-blooded Dalmatian, ganga-territory, in some hybridmimicry status at least, achieved its metonymic climax, with the Croatian metropolis as the topos of its primitive, poverty-stricken rural fascination with its sophisticated heartland.

However, the idyll of national identity discovered in its own 'post-colonial' centre, proved itself to be unstable just where it was enthroned as a falsified warranty of its cultural unity. On the model of the guest-worker collage, the European-ness of Croatian Government ministers at Thompson's concerts burst at the seams of its renovated social nature. At the moment at which their 'democratic right' to take pleasure in their specific taste in music was replaced by criminal prosecution of members of the teenage audiences wearing cocked Ustashi caps, the possibility of the political instrumentalisation of 'Croatian culture' came full circle.

Not even the Riva, as it would turn out, would again be blustered by the 'wind from Dinara [hinterland mountain range]' filling the sails of its exerted parliamentarism. Thompson now howls about national betrayal and the Hague Tribunal as the Judgement Day of a damned civilisation that sacrifices its own people in order to attain material benefit (evading, of course, the issue of his own). Immediately prior to the scandalous rupture in the South, the ant-like democracy of months of Zagreb street protests against the government came to an end and, apart from a single intervention by the police, suffocated itself in its own 'identity labyrinth'. Finding it impossible to formulate simply their existential position, the energy of the protests deflated, bursting again the crags of a host of foisted Christian, democratic, national, European and revolutionary values, and was finally reduced to a politically unprofiled demand for 'bare life'.

The merry parade of pride on the tourist Riviera withdrew that biologicalistic impulse from the extinguished fascination with the metropolis. The last stone of European heresy was pulled in the defence of ganga-territory, proclaiming the location of the ultimately pervading presence of the Eurocentric discourse: in the act that performs monitoring of its own identity. 


\section{REFERENCES}

Bašić, Stanko

2006 Moje vjetrenjače - to hrvatstvo, ta Hrvatska (eseji). Zadar: Udruga 3000 godina Zadra.

\section{Belančić, Milorad}

2005 Razlozi za dekonstrukciju. Beograd: Krug.

Bhabha, Homi

1994 Location of Culture. New York and London: Routledge.

Bosanac, Gordana

2005 Utopija i inauguralni paradoks. Prilogfilozofsko-političkoj raspravi. Zagreb: Kruzak.

Butković, Davor

2001 Hercegovci ne smiju biti žrtve naših kriza (http://www.jutarnji.hr/hercegovci-ne-smiju-biti-zrtvenasih -kriza/588986/).

Ćaleta, Joško

2007 «Stavi prst u uvo, pa goni». Etnomuzikološki i antropološki pregled glazbovanja dalmatinskog zaleđa». In: Prica, Ines and Tea Škokić (eds.), Split i drugi. Kulturnoantropološki i kulturnostudijski prilozi. Zagreb: Institut za etnologiju i fokloristiku (Biblioteka Nova etnografija), 161-182.

Lindstrom, Nicole

2003 Between Europe and Balkans: Mapping Slovenia and Croatia's 'Return to Europe' in the 1990s. Dialectical Anthropology 27 (3-4): 313-329.

Luketić, Katarina

2008 Bijeg s Balkana 2. Zarez 224, 7. 2. 2008, 18.

Marić, Branko

1934 Hercegovačka ganga. In: Hrvatski kalendar. Napredak, 105-107.

Matišić, Mate

2011 Moja dalmatinska zagora je pod zemljom, u šanatorijima. Vrime 10 (portal Imotske novine, 30. 4. 2011).

Melegh, Atila

2006 On the East-West Slope: Globalization, Nationalism, Racism and Discourses on Central and Eastern Europe. Budapest and New York: Verso.

Mijatović, Anđelko

1973 Ganga (pismice iz Hercegovine, Imotske krajine, Duvna, Livna i Kupresa). Duvno: Naša ognjišta (Knj. 4).

Obad, Orlanda

2009 Imperij kao uzvraćanje udarca. Predodžbe o kulturi i identitetu u hrvatskih pregovarača s Europskom unijom. Narodna umjetnost 46 (2): 111-127.

2011 Europska unija u Hrvatskoj. Društvena percepcija iz perspektive postkolonijalne teorije (PhD Dissert, Ms.).

Pavičić, Jurica

200715 laži u koje vjerujemo. Jutarnji list, 3. 5.2007 (http://www.jutarnji.hr/15-lazi-u-koje-vjerujemo/ $172854 /)$.

Petrović, Ankica

1995 Perceptions of Ganga. World of Music 37 (2): 60-71.

Prica, Ines

2007a U potrazi za postsocijalističkim subjektom. Narodna umjetnost 44 (1): 163-186. 
2007b Problemi intepretacije tranzicije iz nerealnog socijalizma. In: Ribić, Vladimir (ed.), Antropologija postsocijalizma. Beograd: Odelenje za etnologiju i kulturnu antropologiju, 24-51.

2009 Political Items on the Ground of the Trivial: Singing politics of Croatian transition. Ethnoanthropozoom 6: 71-93.

2010 Bricolage a la carte. Struktura tranzicijskog mita. In: Marjanić, Suzana and Ines Prica (eds.), Mitski zbornik. Zagreb: Institut za etnologiju i fokloristiku, HED, Scarabeus, 483-494.

Todorova, Maria

1999 Imaginarni Balkan. Beograd: Biblioteka xx vek.

Žanić, Ivo

2003 Simbolični identitet Hrvatske u trokutu raskrižje-predziđe-most. In: Historijski mitovi na Balkanu. Sarajevo: Istorijski institut (http://www.iis.unsa.ba/izdavacka_djelatnost/posebna_izdanja/mitovi/ mitovi.html).

\section{PARADOKS GANGA}

Prispevek namenja pozornost simbolični usodi 'nenavadnega' izraza folklore, ki se je, zahvaljujoč nedvoumni avtentičnosti, prebil na mednarodno zaščiten položaj na seznamu svetovne nesnovne kulturne dediščine, hkrati pa ga spremlja dolgotrajen in nerazrěsen status lokalnega političnega tabuja in subverzivnosti.

$V$ dveh desetletjih hrvaške tranzicije, ki je v senci kulturoloških razprav o hrvaški "pripadnosti Evropi zatemnila in legalizirala gospodarsko-družbeni kriminal izjemnih razsežnosti in nasledkov, se je fenomen ganga razsiril v velik simbolični razpon. S funkcijo svojevrstne okorele družbene mentalitete se je pojavil v kontroverznem razponu: od mitično cistega prostora "pra-evropskib" vrednot, razblinjenih z učinki dekadentne zahodne civilizacije, do povsem nasprotnih oznak družbene regresije v samem jedru oblikovanja identitete, zasnovane na avtizmu in nestrpnosti. Skupinsko petje "na dah" v intervalu velike sekunde, v večglasju, sestavljenem iz začetnega glasu lirskega stiha in dodanih ojkajočih vokalov, je del stoletnega glasbenega sestava in je označeno kot eno zadnjih zatočišč arhaične glasbene misli. Ganga z izrazito drugačnostjo od prevladujočega zahodnega glasbenega kanona in z lirskim verzom, postavljenim v junaško, "hajduško epiko«, $v$ nasprotujočih si recepcijah jasno sledi pravilom socialne stratifikacije - od lokalne privrženosti do souražnosti v mestnih okoljih, kjer gango doživljajo kot grobo, primitivno, netemperirano petje. $V$ strokovnih krogih je gangina pentatonika snov kulturnozgodovinskih ugotovitev že od 30 . let prejšnjega stoletja, pri čemer se ji vzori iščejo v predslovanskem kulturnem substratu, pa tudi v različnih "starih kulturah" po svetu, vključno z glasbo ameriskih "Indijancev«. Da bi jo potrdili kot južnoslovansko tradicijo, $v$ njej vidijo prežitek predslovanske balkanske glasbene prakse, $v$ kateri se je funkcija "moči upora $v$ stoletjih bolečin in bitk z zatiralci " preslikovala $v$ melodični redukciji na diafonijo. To nasprotje zahodnemu glasbenemu kanonu, naturalizirano v fiziološko skoraj nevzdržnem zvočnem "neskladju«, jo ohranja v stalnem fokusu kulturoloških razprav o njenem položaju v nacionalnih izročilih. Kot »divji« element v plemenitosti in skladnosti ljudske duhovne ustvarjalnosti ganga prekriva izjemen obseg interpretacijske moči: od oznak mističnega predkulturnega stanja $z$ univerzalnimi sporočili do simbola okorelosti in lokalne fiksiranosti. 
Omahljivost $v$ nacionalno-estetskih presojah, dodatno podkrepljena z multi-ali transetničnim značajem njenega neugotovljenega izvira, je naposled prekinila uvrstitev gange $v$ Unescov seznam svetovne nesnovne dedišcine. Strokovna presoja se nagiba v prid harmonični polifoniji tesnih intervalov, sčimer je neugledno paranje ušes uradno premě̌čeno $v$ "popoln učinek zvočne enotnosti". Folkloristični značaj te oblike prakticiranja glasbe, ki je ponujal sprejemljivo različico multikulturalizma kot balkanskega, "protoetničnega" amalgama, ni preprečil, da bi se ganga predvsem od 70. let prejšnjega stoletja utrdila kot simbol hrvaškega nacionalizma v njegovem zgubarskem značaju političnega odpadništva in diasporične "gastarbajterske" kulture. V 90. letih je gangina kultura prevzela številne od teh elementov, vendar je v "zmagovalnem " položaju novo pridobljene samostojnosti in razčiščevanja s socializmom (zlasti simboliko trpinčenja pod "komunističnimi zločini “) iz vidika širše regionalne percepcije, pa tudi v hrvaškem ruralno-urbanem nasprotju, postala splošni simbol primitivizma in družbeno-kulturne regresije, nosilka nove plasti mogočnikov iz dalmatinske Zagore in Hercegovine.

Ganga se subkulturnim pozicioniranjem svojih govornih praks še naprej izmika popolni nacionalno-tradicijski uveljavitvi; hkrati je priznano folkloristično določilo nacionalnega prostora in tudi temeljni simbolni kod oblikovanja nepredelanega jedra, "ganginega teritorija" hrvaške evropske pripadnosti.

Dr. Ines Prica, research advisor, Institute of Ethnology and Folklore Research, Šubićeva 42, HR-10000 Zagreb, Croatia, ines@ief.hr 